\title{
COMPARISON BETWEEN THE MICROBIOLOGICAL QUALITY OF KAREISH CHEESE MANUFACTURED FROM RAW AND PASTEURIZED SKIMMED MILK SOLD IN ASSIUT CITY MARKETS
}

\author{
M.F. HUSSIEN; MANAL M. AMIN and O.A. SADEK \\ Animal Health Research Institute, Assiut Lab., Egypt
}

\begin{tabular}{|c|c|}
\hline & ABSTRACT \\
\hline Received at: $25 / 6 / 2013$ & $\begin{array}{l}\text { A total of } 70 \text { random samples of Kareish cheese ( } 35 \text { each of Kareish cheese made } \\
\text { from raw skimmed milk and Kareish cheese made from pasteurized skimmed milk) } \\
\text { were collected from Assiut City markets, supermarkets, groceries and dairy shops. } \\
\text { The average counts of APC, enterococci, Staph. aureus and total yeasts and molds } \\
\text { were } 1.3 \times 10^{7}, 2.4 \times 10^{6}, 1.1 \times 10^{7} \text { and } 3.0 \times 10^{6} \text { cfu/g of the examined raw milk Kareish } \\
\text { cheese samples, respectively. The average values of APC, enterococci, Staph. } \\
\text { aureus and total yeasts and molds were } 2.4 \times 10^{5}, 2.2 \times 10^{3}, 1.8 \times 10^{5} \text { and } 4.3 \times 10^{3} \text { of the } \\
\text { examined pasteurized Kareish cheese samples, respectively. Moreover, kareish } \\
\text { cheese samples made from pasteurized skimmed milk were completely free from } \\
\text { fecal coliforms, E. coli and Listeria monocytogenes. Anaerobic spore formers could } \\
\text { be detected in } 54.3 \text { and } 2.9 \% \text { of the examined Kareish cheese samples made from } \\
\text { raw and pasteurized skimmed milk, respectively. } 20 \% \text { of the examined raw milk } \\
\text { Kareish cheese samples were contaminated with Listeria monocytogenes. The } \\
\text { present study proved that Kareish cheese samples made from pasteurized skimmed } \\
\text { milk was better in microbiological quality than Kareish cheese samples made from } \\
\text { raw skimmed milk which reflect the neglected sanitary conditions under which raw } \\
\text { milk Kareish cheese is produced, therefore, strict hygienic measures should be } \\
\text { adopted during production of raw milk Kareish cheese. The public heath } \\
\text { significance and suggested control measures were discussed. }\end{array}$ \\
\hline
\end{tabular}

Key Words: Kareish cheese, Raw milk, Pasteurized milk

\section{INTRODUCTION}

Kareish cheese is one of the most popular soft, fresh, lactic acid, low salt type of cheese in Egypt, it is prepared from low fat or skimmed buffalo or cow's milk and contain all the skimmed milk constituents including proteins, sugar, some of water soluble vitamins and most of the calcium and phosphorous compounds originally present in the milk.

Likewise, kareish cheese can be considered a good medium for microbial growth due to their nutrient content and long storage duration, several steps in their production can cause microbiological hazards.

Pasteurization of milk can destroy most of the pathogens posing risk to public health, however the potential bacteriological hazards can still be found in the final products after pasteurization through the addition of contaminated ingredients or improper handling (Omar, 2006).

Kareish cheese is considered the main protein supplement to farmers and most people in Egypt, the main sources of pathogenic microorganisms in cheese are contaminated raw milk, food handlers, dust, utensils and insects (Robinson, 1990).
The growth of pathogenic microorganisms in dairy products influenced by thermal treatment during processing and by conditions within the product such as $\mathrm{pH}$, water activity, presence of inhibitory or competitive microorganisms (Ray, 1996).

Kareish cheese is one of the ancient Egyptian fresh white soft cheeses. It is consumed largely in Egypt due to its low price and high nutritive value. It is made mainly at farmer's house either by acid coagulation of skimmed milk by natural microflora present in milk or by addition of rennet to skimmed milk, such methods of manufacturing are still primitive and unhygienic, a fact that may expose the product to serious contamination (Ahmed and ElBassiony, 1977 and Deeb et al., 2004).

The microbiological quality and safety of Kareish cheese are the major area of concern for both producers and consumers. The coliforms and total bacterial counts are used as indicators for both sanitary quality and shelf life of the cheese. However, there have been a number of serious well documented outbreaks of food borne diseases associated with consumption of cheeses. Furthermore, cheeses made from raw milk are particularly at risk since they may become contaminated with pathogens initially present 
in the milk. Pathogens may also enter cheese during processing, if hygienic and process controls are inadequate (Fernandes, 2008). Therefore, the present work was planned to investigate the microbiological status of Kareish cheese made from raw skimmed milk and Kareish cheese made from pasteurized skimmed milk, as well as, to secure the incidence of Listeria monocytogenes and anaerobic spore formers in both types of cheeses.

\section{MATERIALS and METHODS}

\section{I-collection of samples:}

A total of 70 random samples of Kareish cheese made from raw skimmed milk and Kareish cheese made from pasteurized skimmed milk (35 of each) were collected from different markets, shops and supermarkets in Assiut City, Egypt. The collected samples were sent to the laboratory in an insulated box with a minimum of delay to be examined.

\section{II-Microbiological analysis:}

Representative 11 gram of each sample were aseptically homogenized in $99 \mathrm{ml}$ of sterile $2 \%$ sodium citrate solution in a stomacher for 1 minute. Ten fold serial solutions were prepared using sterile saline and appropriate dilutions were used for determination of the following:-

1- Aerobic plate count (APC) (APHA, 1992).

2- Coliforms count (MPN/g) (AOAC, 1980).

3- Fecal coliforms count (MPN/g) (AOAC, 1980).

4- E. coli count (MPN/g) (AOAC, 1980).

5- Enterococci count (Deibel and Hartman, 1982).

6- Enumeration and isolation of Staph. aureus (Baird-Parker, 1962).

7- Total yeasts and molds count (Harrigan and MeCance, 1976).

III-Isolation and identification of Listeria monocytogenes (Fiengold and Martin, 1982).

IV-Detection of anaerobes (Cruickshank et al., 1970).

\section{RESULTS}

Table 1: Incidence of different microorganisms isolated from Kareish cheese made from raw milk and Kareish cheese made from pasteurized milk.

\begin{tabular}{|c|c|c|c|c|c|c|c|c|c|c|c|c|c|c|}
\hline \multirow[t]{2}{*}{ Product } & \multicolumn{2}{|c|}{ APC } & \multicolumn{2}{|c|}{$\begin{array}{c}\text { Total } \\
\text { coliforms }\end{array}$} & \multicolumn{2}{|c|}{$\begin{array}{c}\text { Fecal } \\
\text { coliforms }\end{array}$} & \multicolumn{2}{|c|}{ E. coli } & \multicolumn{2}{|c|}{ Enterococci } & \multicolumn{2}{|c|}{$\begin{array}{l}\text { Staph. } \\
\text { aureus }\end{array}$} & \multicolumn{2}{|c|}{$\begin{array}{c}\text { Yeasts \& } \\
\text { molds }\end{array}$} \\
\hline & No. & $\%$ & No & $\%$ & No & $\%$ & No & $\%$ & No & $\%$ & No & $\%$ & No & $\%$ \\
\hline $\begin{array}{l}\text { Kareish cheese } \\
\text { from raw milk } \\
\text { (No. 35) }\end{array}$ & 35 & 100 & 34 & 97.1 & 34 & 97.1 & 28 & 80 & 23 & 65.7 & 30 & 85.7 & 25 & 71.4 \\
\hline $\begin{array}{l}\text { Kareish cheese } \\
\text { from pasteurized } \\
\text { milk (No. 35) }\end{array}$ & 26 & 74.3 & 6 & 17.1 & 0 & 0 & 0 & 0 & 15 & 42.9 & 25 & 71.4 & 23 & 65.7 \\
\hline
\end{tabular}

Table 2: Microbial profiles of Kareish cheese samples made from raw skimmed milk cfu/g.

\begin{tabular}{cccc}
\hline Organisms & Min. & Max. & Average \\
\hline APC & $5.1 \times 10^{2}$ & $1.2 \times 10^{8}$ & $1.3 \times 10^{7}$ \\
\hline Enterococci & $3.2 \times 10^{3}$ & $6.1 \times 10^{7}$ & $2.4 \times 10^{6}$ \\
\hline Staph. aureus & $3.1 \times 10^{3}$ & $1.0 \times 10^{8}$ & $1.1 \times 10^{7}$ \\
\hline Yeasts \& molds & $3.0 \times 10^{2}$ & $3.6 \times 10^{7}$ & $3.0 \times 10^{6}$ \\
\hline
\end{tabular}

Table 3: Microbial profiles of Kareish cheese samples made from pasteurized skimmed milk cfu/g.

\begin{tabular}{cccc}
\hline Organisms & Min. & Max. & Average \\
\hline APC & $4.0 \times 10^{2}$ & $3.3 \times 10^{6}$ & $2.4 \times 10^{5}$ \\
\hline Enterococci & $1.0 \times 10^{2}$ & $2.3 \times 10^{4}$ & $2.2 \times 10^{3}$ \\
\hline Staph. aureus & $3.0 \times 10^{2}$ & $3.2 \times 10^{6}$ & $1.8 \times 10^{5}$ \\
\hline Yeasts \& molds & $1.0 \times 10^{2}$ & $2.6 \times 10^{4}$ & $4.3 \times 10^{3}$ \\
\hline
\end{tabular}


Assiut Vet. Med. J. Vol. 59 No. 138 July 2013

Table 4: Frequency distribution of the examined Kareish cheese samples made from raw skimmed milk based on different microbial counts/g (No. 35).

\begin{tabular}{|c|c|c|c|c|c|c|c|c|c|c|c|c|c|c|}
\hline \multirow[t]{2}{*}{ Counts/g } & \multicolumn{2}{|c|}{ APC } & \multicolumn{2}{|c|}{$\begin{array}{c}\text { Total } \\
\text { coliforms }\end{array}$} & \multicolumn{2}{|c|}{$\begin{array}{c}\text { Fecal } \\
\text { coliforms }\end{array}$} & \multicolumn{2}{|c|}{ E. coli } & \multicolumn{2}{|c|}{$\begin{array}{l}\text { Enterococ } \\
\quad \text { ci }\end{array}$} & \multicolumn{2}{|c|}{$\begin{array}{l}\text { Staph. } \\
\text { aureus }\end{array}$} & \multicolumn{2}{|c|}{$\begin{array}{c}\text { Yeasts \& } \\
\text { molds }\end{array}$} \\
\hline & No. & $\%$ & No. & $\%$ & No. & $\%$ & No. & $\%$ & No. & $\%$ & No. & $\%$ & No. & $\%$ \\
\hline $3-<10$ & 0 & 0 & 0 & 0 & 9 & 25.7 & 16 & 45.7 & 12 & 34.2 & 5 & 14.3 & 11 & 31.4 \\
\hline $10-<10^{2}$ & 0 & 0 & 0 & 0 & $\overline{0}$ & 0 & 6 & 17.1 & 0 & 0 & 0 & 0 & 0 & 0 \\
\hline $10^{2}-<10^{3}$ & 7 & 20 & 1 & 2.9 & 4 & 11.4 & 3 & 8.6 & 0 & 0 & 0 & 0 & 3 & 8.6 \\
\hline $10^{3}-<10^{4}$ & 0 & 0 & 34 & 97.1 & 22 & 62.9 & 10 & 28.6 & 1 & 2.9 & 2 & 5.7 & 3 & 8.6 \\
\hline $10^{4}-<10^{5}$ & 6 & 17.1 & 0 & 0 & 0 & 0 & 0 & 0 & 9 & 25.7 & 2 & 5.7 & 7 & 20 \\
\hline $10^{5}-<10^{6}$ & 7 & 20 & 0 & 0 & 0 & 0 & 0 & 0 & 7 & 20 & 3 & 8.6 & 4 & 11.4 \\
\hline $10^{6}-<10^{7}$ & 8 & 22.9 & 0 & 0 & 0 & 0 & 0 & 0 & 5 & 14.3 & 9 & 25.7 & 3 & 8.6 \\
\hline $10^{7}-<10^{8}$ & 5 & 14.3 & 0 & 0 & 0 & 0 & 0 & 0 & 1 & 2.9 & 13 & 37.1 & 4 & 11.4 \\
\hline $10^{8}-<10^{9}$ & 2 & 5.7 & 0 & 0 & 0 & 0 & 0 & 0 & 0 & 0 & 1 & 2.9 & 0 & 0 \\
\hline Total & 35 & 100 & 35 & 100 & 35 & 100 & 35 & 100 & 35 & 100 & 35 & 100 & 35 & 100 \\
\hline
\end{tabular}

Table 5: Frequency distribution of the examined Kareish cheese samples made from pasteurized skimmed milk based on different microbial counts/g (No. 35).

\begin{tabular}{|c|c|c|c|c|c|c|c|c|c|c|c|c|c|c|}
\hline \multirow[t]{2}{*}{ Counts/g } & \multicolumn{2}{|c|}{ APC } & \multicolumn{2}{|c|}{$\begin{array}{c}\text { Total } \\
\text { coliforms }\end{array}$} & \multicolumn{2}{|c|}{$\begin{array}{l}\text { Fecal } \\
\text { coliforms }\end{array}$} & \multicolumn{2}{|c|}{ E. coli } & \multicolumn{2}{|c|}{ Enterococci } & \multicolumn{2}{|c|}{$\begin{array}{l}\text { Staph. } \\
\text { aureus }\end{array}$} & \multicolumn{2}{|c|}{$\begin{array}{l}\text { Yeast \& } \\
\text { molds }\end{array}$} \\
\hline & No. & $\%$ & No. & $\%$ & No. & $\%$ & No. & $\%$ & No. & $\%$ & No. & $\%$ & No. & $\%$ \\
\hline $3-<10$ & 9 & 25.7 & 33 & 94.3 & 35 & 100 & 35 & 100 & 20 & 57.1 & 11 & 31.5 & 12 & 34.3 \\
\hline $10-<10^{2}$ & 0 & 0 & 2 & 5.7 & 0 & 0 & 0 & 0 & 0 & 0 & 0 & 0 & 0 & 0 \\
\hline $10^{2}-<10^{3}$ & 1 & 2.9 & 0 & 0 & 0 & 0 & 0 & 0 & 1 & 2.9 & 4 & 11.4 & 5 & 14.3 \\
\hline $10^{3}-<10^{4}$ & 13 & 37.1 & 0 & 0 & 0 & 0 & 0 & 0 & 12 & 34.3 & 9 & 25.7 & 12 & 34.3 \\
\hline $10^{4}-<10^{5}$ & 7 & 20 & 0 & 0 & 0 & 0 & 0 & 0 & 2 & 5.7 & 5 & 14.3 & 6 & 17.1 \\
\hline $10^{5}-<10^{6}$ & 3 & 8.6 & 0 & 0 & 0 & 0 & 0 & 0 & 0 & 0 & 4 & 11.4 & 0 & 0 \\
\hline $10^{6}-<10^{7}$ & 2 & 5.7 & 0 & 0 & 0 & 0 & 0 & 0 & 0 & 0 & 2 & 5.7 & 0 & 0 \\
\hline Total & 35 & 100 & 35 & 100 & 35 & 100 & 35 & 100 & 35 & 100 & 35 & 100 & 35 & 100 \\
\hline
\end{tabular}

Table 6: Incidence of Listeria monocytogenes in the examined Kareish cheese samples.

\begin{tabular}{cccc}
\hline \multirow{2}{*}{ Product } & \multirow{2}{*}{ No. of the examined samples } & \multicolumn{2}{c}{ Positive samples } \\
\cline { 3 - 4 } & 35 & No. & $\%$ \\
\hline Kareish cheese made from raw skimmed milk & 35 & 0 & 20 \\
\hline $\begin{array}{c}\text { Kareish cheese made from pasteurized } \\
\text { skimmed milk }\end{array}$ & 70 & 7 & 0 \\
\hline Total & 30 \\
\hline
\end{tabular}

Table 7: Incidence of anaerobic spore former bacteria in the examined Kareish cheese samples based on the stormy fermentation test.

\begin{tabular}{cccc}
\hline Product & No. of the examined samples & \multicolumn{2}{c}{ Positive samples } \\
\cline { 3 - 4 } & & No. & $\%$ \\
\hline $\begin{array}{c}\text { Kareish cheese made from raw skimmed } \\
\text { milk }\end{array}$ & 35 & 19 & 54.3 \\
\hline $\begin{array}{c}\text { Kareish cheese made from pasteurized } \\
\text { skimmed milk }\end{array}$ & 35 & 1 & 2.9 \\
\hline Total & 70 & 20 & 28.6 \\
\hline
\end{tabular}




\section{DISCUSSION}

From the summarized results presented in Tables 1, 2 and 3, it is clear that $100 \%$ of the Kareish cheeses samples made from raw skimmed milk and $74.3 \%$ of Kareish cheese samples made from pasteurized skimmed milk were contaminated by aerobic bacteria with average $1.3 \times 10^{7}$ and $2.4 \times 10^{5}$ for both types of cheeses, respectively, with the highest frequency distribution lies within rang of $10^{6}-<10^{7}(22.9 \%)$ and $10^{3}-<10^{4}(37.1 \%)$ for both types of cheeses, respectively, (Tables 4\&5). Higher results for raw Kareish cheese samples were reported by Ahmed and El-Bassiony (1977), Ahmed et al. (1987), Aman (1994), Kaldes (1997) and Amin et al. (2001) as they reported, $2.56 \times 10^{7}, 2.65 \times 10^{7}, 2.44 \times 10^{10}, 2.6 \times 10^{8}$ and $2.9 \times 10^{9} \mathrm{cfu} / \mathrm{g}$, respectively. While, Omar (2006) recorded that, the mean of total bacterial count is $1 \times 10^{9}$ for opened Kareish cheese samples and $2.40 \times 10^{8}$ for packed Kareish cheese samples.

Most foods especially dairy products should be regarded as unsatisfactory where they have a large population of microorganisms even if the organisms are not know to be pathogens for several reasons. Higher aerobic palate counts often indicate contaminated raw materials or unsatisfactory processing from sanitary point of view, as some strains not usually regarded as causing food borne diseases have been reported to cause illness when excessive numbers of living cells present in food.

From the obtained results in this study, it is clear that pasteurized milk Kareish cheese has lower APC than raw milk Kareish cheese.

Table 1 revealed that, $34(97.1 \%)$ of the examined Kareish cheese samples made from raw milk and 6 $(17.1 \%)$ of the examined Kareish cheese samples made from pasteurized skimmed milk were contaminated with coliforms, the highest frequency distribution lies within the range of $10^{3}-<10^{4}$ $(97.1 \%)$ and $3-<10(94.3 \%)$, respectively (Tables 4,5). Many reports dealing with the occurrence of coliforms in Kareish cheese samples made from raw skimmed milk have been reported, in those studies, various rates of coliforms were showed as $87,96,84$, $80,80,100,92,76.7,98.8$ and $70 \%$ by Ahmed et al. (1987); Sheliah et al. (1987); Ahmed et al. (1988); Aman (1994); Amin et al. (2001); El-Kosi (2001); Moawad et al. (2002); Hassan (2003); Deeb et al. (2004) and Abou-Ahmed (2007), respectively. Omar (2006) revealed that, the mean of total coliforms count were $1 \times 10^{9}$ for open Kareish samples and $2.4 \times 10^{8}$ for packed Kareish cheese samples.

Coliforms bacteria are able to tolerate the acid and salt conditions of most cheeses, they are not inhibited by the starter bacteria, they ferment lactose readily and grow well at the temperatures used in making most varieties of cheese (Chapman and Sharpe,
1990). Not less than $9.5 \% \mathrm{NaCl}$ should be added to suppress the growth of coliforms in cheese made from raw milk (Abd El-Salam and Alichanidis, 2004).

High levels of coliforms in cheese may indicate unsanitary practices in cheese making process and may sometimes give rise to early blowing or gassing of the product. It is characterized by large gas holes, a spongy texture of cheese and generally occurs $1-2$ days after manufacture (Bintsis, 2006), generally presence of coliforms in cheese is considered as an index of unsatisfactory sanitation and possible presence of enteric pathogens (Frazier and Westhoff, 1987).

It is clear that, Kareish cheeses samples made from raw skimmed milk were highly contaminated with coliforms than Kareish cheeses samples made from pasteurized skimmed milk and this means that raw Kareish cheese samples unacceptable from the microbiological point of view in comparison to the pasteurized Kareish cheese, and that is confirmed by Omar (2006) who recorded that the unacceptable Kareish cheese samples according to total coliforms were $3(37.5 \%)$ of the 8 known brand Kareish cheese samples, $2(20 \%)$ of the 10 unknown brand packed Kareish cheese samples and 49 (79\%) of the 62 open Kareish cheese samples.

Likewise, $97.1 \%$ of the examined Kareish cheese samples made from raw skimmed milk were contaminated with fecal coliforms, while, all samples of Kareish cheese made from pasteurized skimmed milk were completely free from fecal coliforms (Table 1). The highest frequency distribution of fecal coliforms contamination of Kareish cheese samples made from raw skimmed milk lies within the range of $10^{3}-<10^{4}(62.9 \%)$ (Table 4$)$, nearly similar results $93.3 \%$ and $96 \%$ were revealed by El-Mossalami (1999) and Meshref and Hassan (2009), respectively. Lower results were recorded by Omar (2006) which were $4(50 \%)$ of the 8 known brand packed Kareish cheese samples, $4(40 \%)$ of the unknown brand packed Kareish cheese samples. However, 56 (90.3\%) of the 62 opened Kareish cheese samples, and the mean numbers of fecal coliforms in opened Kareish cheese samples were $3.8 \times 10^{2}$ and $3.2 \times 10^{2}$ bacteria/g for packed Kareish cheese samples, the author stated that, the difference between the rate of contamination of samples of known and unknown brands of Kareish cheese with coliforms and fecal coliforms were non significant, while, between packed and opened Kareish cheese samples was statistically significant.

The aforementioned results confirm that pasteurized milk Kareish cheese is better than raw milk Kareish cheese due to pasteurization process greatly minimize the coliforms and fecal coliforms counts which considered indicators for contamination of the product. 
E. coli is an indicator of fecal contamination and presence of enteric pathogens, E. coli was found in 28 $(80 \%)$ of the examined Kareish cheese samples made from raw skimmed milk with the highest frequency distribution lies within the range of $3-<10(45.7 \%)$ (Tables 1\&4). While, all the examined Kareish cheese made from pasteurized skimmed milk were free from E. coli (Table 1).

According to the published data, E. coli was detected in raw milk Kareish cheese by Ahmed and ElBassiony (1977); Aboul-Khier et al. (1985); Ahmed et al. (1987); Sheliah et al. (1987); El-Kholy (1989); Aman (1994); Kaldes (1997); El-Shishnagui and Nazem (1999); Amin et al. (2001); Hassan (2003); Bahout and Moustafa (2006) and Mezyed et al. (2008) with incidences of $76,80.95,75,36,23.33$, $47.5,80,46.7,49.33,43.33,50$ and $43.3 \%$, respectively.

Omar (2006) estimated that, the mean E. coli counts in open Kareish cheese samples were $3.8 \times 10^{2}$ and $4.4 \times 10$ in packed Kareish cheese samples and the unacceptable Kareish cheese samples according to E. coli were $4(50 \%)$ samples of 8 known brand packed Kareish cheese samples, 4 (40\%) samples of the 10 known brand packed Kareish cheese samples and $52(83.9 \%)$ samples of the 62 open Kareish cheese samples.

The presence of E. coli in food is considered as an indicator of fecal contamination, moreover, particular strains are known to induce severe diarrhea in both infants and young children, as well as, cases of food poisoning and gastroenteritis among adult consumers (Eley, 1996).

Enterococci are normally present in faeces and also occur in environment, their detection in dairy products in large numbers implies either inadequate sanitary practices or exposure of the food to condition that would permit extensive multiplication of such bacteria, likewise, they have been implicated in some cases of food poisoning (George and Uttley, 1989). $23(65.7 \%)$ and $15(42.9 \%)$ of Kareish cheese samples made from raw and pasteurized skimmed milk were contaminated with enterococci (Table 1) and the average counts were $2.4 \times 10^{6}$ and $2.2 \times 10^{3}$ cells/g for both types of cheese, respectively (Tables $2 \& 3)$ with the highest frequency distribution lies within the range of $3-<10(34.2 \%)$ and $3-<10$ $(57.1 \%)$ for both types of cheese samples, respectively (Tables 4\&5). Higher incidence (100\%) with higher average of $5.7 \times 10^{6}$ were recorded by Bahout and Moustafa (2006) for the examined Kareish cheese samples made from raw skimmed milk, also higher result was noticed by Amer (1982) who stated the average count of enterococci from raw Kareish cheese samples was $41.5 \times 10^{6} / \mathrm{g}$. Generally, it is clear that pasteurized milk Kareish cheese has lower incidence of enteroccocci than raw milk Kareish cheese and this may attributed to the efficiency pasteurization process which destruct pathogenic organisms and reduced total number of bacteria.

On the other hand, Staph. aureus was detected in 30 $(85.7 \%)$ and $25(71.4 \%)$ with average counts of $1.1 \times 10^{7}$ and $1.8 \times 10^{5}$ organisms/g with high frequency distribution lies within range of $10^{7}-<10^{8}(37.1 \%)$ and within range of $3-<10(31.4 \%)$ for the examined Kareish cheese samples made from raw and pasteurized skimmed milk, respectively (Tables 1-5). Lower results were detected by Bahout and Moustafa (2006) in an incidence of $28 \%$ in raw Kareish cheese samples with mean value of $3.4 \times 10^{4} \pm 0.9 \times 10^{4} \mathrm{cfu} / \mathrm{g}$, and highest frequency percentage $(31.7 \%)$ lay within the range of $10^{4}$ and $10^{5}$.

The presence of Staph. aureus in cheese usually indicate contamination of milk from diseased udder or external sources including dairy animals, hands, sneezing and coughing of dairy workers. Sabioni et al. (1988) reported an outbreak of food poisoning in Brazil from cheese contaminated with staph. aureus at level of $9.3 \times 10 / \mathrm{g}$, and the staph. aureus has a potential importance to the public health because of its ability to produce enterotoxins resulting in staphylococcal food poisoning (Hill, 1983).

Presence of Staph. aureus in pasteurized milk Kareish cheese in this study may be due to either inefficient pasteurization or post pasteurization contamination during handling and marketing.

Kareish cheese samples made from raw skimmed milk and those made from pasteurized skimmed milk were contaminated with yeasts and molds in a percentage of $71.4 \%$ and $65.7 \%$ (Table 1), respectively and with average counts of $3.02 \times 10^{6}$ and $4.3 \times 10^{3} \mathrm{cfu} / \mathrm{g}$, respectively (Tables $2 \& 3$ ). The highest frequency distribution lies within the range of $3-<$ $10(31.4 \%)$ and $10^{3}-<10^{4}(34.3 \%)$ for both types of cheese, respectively (Tables $4 \& 5$ ). Total yeasts and molds counts could be detected in higher rate of $2.4 \times 10^{7}$ by Kaldes (1997) for Kareish cheese samples made from raw skimmed milk.

Yeasts and molds counts in cheese are used as an index of the proper sanitation quality, defects in these unripened soft cheese such as rancidity, softness and colour defects arise mainly from contamination by yeasts and molds. Moreover, in view of the potential ability of some molds to produce mycotoxins during their growth, thus their presence posses potential hazards to food safety and human health (Rippon, 1982 and Kivance, 1990).

Economically, presence of yeasts and molds in dairy products is undesirable even found in few numbers 
because they rapidly grew in a wide range of temperature, $\mathrm{pH}$ and humidity resulting in objectionable changes that render the product in inferior quality or even unmarketable (Mossel, 1982). Fungal growth predominate in dairy products with high growth over bacteria (Cousin et al., 1992).

Furthermore, seven isolates of Listeria monocytogenes (20\%) were recovered from Kareish cheese samples made from raw skimmed milk, while all samples of Kareish cheese made from pasteurized skimmed milk were completely free from this pathogen (Table 6).

Listeria monocytogenes could be isolated from $1.6 \%$ of the examined raw milk Kareish cheese samples (Wahba, 2002) which is nearly similar to findings obtained by Fathi and Saad (1992) and Khalil and Bastawrows (1997) while, higher incidences of the organism in raw milk Kareish cheese, identified from $16.6 \%$ of the examined Kareish cheese samples (Abdel-Hady et al., 1996) which is similar to this study.

The existence of Listeria monocytogenes in Kareish cheese samples made from raw milk could be attributed to infected or contaminated raw milk used, high $\mathrm{pH}$ value, high moisture content, the primitive way of processing, handling and methods of selling of this particular type of cheese. Moreover, these products are sometimes referred to as acid-curd cheese and the refrigerated shelf life of these soft cheese is typically less than 60 days, these factors either single or collectively represent a public health hazard and risk for human exposure to such organism. Although, the use of unpasteurized milk for cheese making of great concern, Listeria monocytogenes has been isolated from pasteurized milk cheese (Breer, 1986 and Terplan et al., 1986).

Recontamination would generally seem to be of considerable greater importance than improper pasteurization. The contamination of sot cheese is often caused by using insufficiently sanitized equipment (Terplan et al., 1990) or from cow barns during milking process and multiply in milk tank as the organism has psychrotrophic nature (Husu et al., 1990).

Soft cheeses have received particular attention as a source of Listeria monocytogenes since an outbreak of listeriosis in California implicating Mexican-style soft cheese (James et al., 1985). In the aftermath of this outbreak, soft cheeses were the subjects of high level of surveillance and isolation of Listeria monocytogenes was reported from different types of cheeses.

It is clear that pasteurized milk Kareish cheese sample have no L. monocytogenes (Table 6) and this may attributed to pasteurization process that destroy all pathogenic organisms.

In this study $19(54.3 \%)$ of Kareish cheese samples made from raw skimmed milk were contaminated with anaerobic spore formers, while only one (2.9\%) of the examined Kareish cheese made from pasteurized skimmed milk was contaminated with this type of bacteria (Table 7).

Presence of anaerobes is indicative for unhygienic conditions during manufacture, which could be dangerous especially for children because spores could colonize and produce toxins in their intestine. Heat resistant spores of anaerobes could be germinate at cooling temperature, multiply rapidly and produce toxins that cause the symptoms of food poisoning. Awareness should be directed towards the incidence of such type of bacteria due to their thermoduric nature, as well as, their ability to multiply at refrigeration temperature (Sayed and Abdel-Haleem, 2005).

It is evident that pasteurized milk Kareish cheese samples have lower incidence of anaerobic spore formers than raw milk Kareish cheese samples (Table 7) which confirm the importance of using pasteurized milk in milk product manufacturing.

From the after mention results obtained in this study and according to the guideline for the microbiological quality of ready-to-eat foods proposed Gilbert et al. (2006), Kareish cheese samples made from raw skimmed milk were unsatisfactory for high extent depending on all criteria of evaluation. Although Kareish cheese made from pasteurized skimmed milk were completely free from fecal coliforms, E. coli and Listeria monocytogenes, they were contaminated for high extent with APC, enterococci, Staph. aureus, yeasts and molds which may be attributed to the post manufacturing contamination, improper handling and storage.

In conclusion the microbiological quality of Kareish cheese samples made from pasteurized skimmed milk were superior than Kareish cheese samples made from raw skimmed milk and the average counts in all tested microbial parameters were higher in Kareish cheese samples made from raw skimmed milk than Kareish cheese samples made from pasteurized skimmed milk.

Therefore, to safeguard consumers from being infected and to obtain Kareish cheese of good keeping quality, recommendations should be applied to use pasteurized skimmed milk in manufacturing of Kareish cheese and strict hygienic measures should be adopted during manufacturing and storage. 


\section{REFERENCES}

$A O A C$ (1980): Official methods of analysis. $15^{\text {th }}$ Ed., Association of Official Analytical Chemists, Benjamin Franklin Station, Washington, USA.

A.P.H.A. (1992): Standard methods for examination of dairy products. $13^{\text {th }}$ Ed., American Public Heath Association, Washington, DC, USA.

Abdel-Hady, H.M.; Moawad, A.A. and Abou-Zeid, A.M. (1996): Validation of simple method for rapid detection of Listeria monocytogenes in raw milk and Kareish cheese. Vet. Med. J. Giza, 44: 209-213

Abd El-Salam, M.H. and Alichanidis, E. (2004): Cheese varites ripened in brine. In cheese chemistry, physics and microbiology, Vol. 2, pp. 227-249, $3^{\text {rd }}$ Ed., Edited by Fox, P.F.; McSweeney, P.L.; Cogan, T.M. and Guinee, T.P. Academic Press Publisher.

Abou-Ahmed, B.N. (2007): Hygienic quality of soft cheese marketed in Cairo. M.V.Sc. Thesis, Fac. Vet. Med., Cairo Univ., Egypt.

Aboul-Khier, F.A.; El-Bassiony, T. and Gad El-Rab, H. (1985): Enterobacteriaceae in some milk products in Sohag City. Assiut Vet. Med. J., 14 (28): 80-85.

Ahmed, A.A.; Ahmed, S.H. and Moustafa, K.M. (1988): Occurrence of fecal coliforms and enteric pathogenic E. coli in Egyptian soft cheese. J. Food Prot., 51 (6): 442-444.

Ahmed, AA. and El-Bassiony, T.A. (1977): Studies on Kareish cheese in upper Egypt. IIMicrobiological studies. Assiut Vet. Med. J., 4 (8): 103-111.

Ahmed, A.A.; Moustafa, M.K. and Abdel-Hakiem, E.H. (1987): Sanitary condition of Kareish cheese manufactured in Assiut City. Assiut Vet. Med. J., 19 (37): 75-80.

Aman, I.M. (1994): Microbiological quality of Kareish cheese in Kafr El-Sheikh City. Assiut Vet. Med. J., 31 (61): 182-189.

Amer, I. (1982): Microbiological studies on locally manufactured cheese in Zagazyge markets. Ph.D. Thesis, Fac. Vet Med., Zagazig Univ., Egypt.

Amin, A.A.; El-Leboudy, Ahlam, A.; Nazem, A.M.; Bakhieat, A.A. and Kheuralla, H. (2001): Microbial criteria of Damietta and Kareish cheese in Bohaira Governorate. The $2^{\text {nd }}$ international conference. Fac. Vet. Med., Mansoura Univ., Egypt, 8-9 April, 2001, 183-199.

Bahout, A.A. and Moustafa, A.H. (2006): Occurrence of some microorganisms in relation to public health in Kareish cheese. Assiut Vet. Med. J., 52 (111): 85-92.

Baird-Parker, A.C. (1962): An approved diagnostic and selective medium for isolation of coagulase positive staphylococci. J. App. Bacteriol., 25:12.
Bintsis, T. (2006): Quality of brine. In Brined cheese, Edited by Tamime, A. pp. 264-301. Blackwell Publishing.

Breer, C. (1986): The Occurrence of Listeria spp. in cheese. Proceeding $2^{\text {nd }}$ World Congress Foodborne Infections and Intoxication, 1: 230-233.

Chapman, T.L. and Sharpe, M.E. (1990): Microbiology of cheese. In: Dairy microbiology, Vol. 2: The microbiology of milk products, $2^{\text {nd }}$ Ed., Ediated by R.K. Robinson, Elsevier science publishing Co. Inc., USA.

Cousin, M.A.; Jay, J.M. and Vasavada, P.C. (1992): Psychrotrophic Microorganisms. In: Compendium of Foods. Vandezant, C. and Splillstoessor, D.F. (eds.), $3^{\text {rd }}$ ed., 153-168. APHA, Washington, D.C., USA.

Cruickshank, R.; Duguid, I.P. and Swain, R.H. (1970): Medical Microbiology, $11^{\text {th }}$ Ed., E. Living Stone Ltd., Edinburgh.

Curtis, G.D.; Mitchell, R.G.; King, A.F. and Griffin, E.J. (1989): A selective differential medium for the isolation of Listeria monocytogenes. Lett. Appl. Microbiol., 8: 95-98.

Deeb, Azza, M.M.; Aman, I.M. and Ahmed, H.F. (2004): Bacteriological quality of Kareish cheese and a trial to control Staph. aureus in cheese. Alex. J. Vet. Sci., 21(2): 514-523.

Deibel, R.H. and Hartman, P.A. (1982): The enterococci in compendium of methods for the microbiological examination of foods. Speck, M.L, $2^{\text {nd }}$ Ed., APHA, Inc.

El-Kholy, A.M. (1989): Enterobacteriaceae in Egyptian soft cheese and their public health significance. Assiut Vet. Med. J., 21 (42): 70-75.

El-Kosi, O.H. (2001): Occurrence of some enteric pathogens and their indicators in some Egyptian raw milk products. Assiut Vet. Med. J., 45 (89): 48-61.

El-Mossalami, Hanaa, H.A. (1999): Occurrence of fecal coliforms and enteropathogenic $E$. coli in soft cheese in Alexandria. M.V.Sc. Thesis, Fac. Vet. Med., Alex. Univ., Egypt.

El-Shishnagui, S.M. and Nazem, A.M. (1999): Prevalence of enterotoxigenic E. coli in soft cheese as determined by PCR assay. Alex. J. Vet. Sci., 15 (2): 451-462.

Eley, A.R. (1996): Microbial Food Poisoning $2^{\text {nd }}$ Ed., Chapman and Hall. London, U.K.

Fathi, S.M. and Saad, Nagah, M. (1992): A survey of some selected food items for the presence of Listeria monocytogenes and other Listeria species. Assiut Vet. Med. J., 27 (54): 114-120.

Fernandes, R. (2008): Microbiological hand book dairy products. Letherhead publishing, UK.

Finegold, S.M. and Martin, W.J. (1982): Bailey and Scott Diagnostic Microbiology. $6^{\text {th }}$ Ed., C.V. Mosby Co. St. Louis, Toronto, London. 
Frazier, W.C. and Westhoff, D.C. (1978): Food Microbiology. $3^{\text {rd }}$ Ed., McGraw Hill Book Co. New York.

George, R.C. and Uttley, A.H. (1989): Susceptibility of enterococci and epidemiology of enterococcal infections in the $1980 \mathrm{~s}$. Epid Inf., 102: 403-441.

Gilbert, R.J.; De Louvois, J.; Donavan, T.; Little, C.; Nye, K.; Ribeiro, C.D.; Richards, J.; Roberts, D. and Boltan, F.J. (2000): Guidelines for the microbiological quality of some ready-to-eat foods sampled at the point of sale. Commun. Dis. Public Health, 3: 163.

Harrigan, W.F. and MeCance, M.E. (1976): Laboratory methods in food: Dairy Microbiology. Academic Press London, New York, San Francisco, USA.

Hassan, G.M. (2003): Quality assessment of some dairy products at consumer level. Ph.D. Thesis, Fac. Vet. Med., Beni-Seuf branch, Cairo Univ., Egypt.

Hill, B.M. (1983): $\quad$ Enterotoxin-producing Staphylococcus aureus isolated from milk and dairy products. New Zealand J. Dairy Sci. Technology, 18, 59-62.

Husu, J.R.; Seppanen, J.T.; Sivela, S.K. and Rauramaa, A.L. (1990): Contamination of raw milk by Listeria monocytogenes in dairy farms. J. Vet. Med., 37: 268-275.

James, S.M.; Fannin, S.L.; Agree, B.A.; Hall, B.; Parker, E.; Vogt, J.; Run, G.; Williams, J.; Leib, L.; Salminen, C.; Prendergast, T.; Wener, S.B. and Chin, J. (1985): Listeriosis outbreak associated with Mexican-Style cheese in California. J. Amer. Med. Assoc., 254-274.

Kaldes, Y.T. (1997): Microbiological examination of sot cheese manufactured in Minia City. Assiut Vet. Med. J., 38 (75): 39-47.

Khalil, Nawal, G. and Bastawrows, A.F. (1997): Isolation of Listeria species from raw milk and some dairy products. Assiut Vet. Med. J., 36 (72): 193-202.

Kivance, M. (1990): Mould growth and presence of aflatoxin in some Turkish cheese. J. Food Safety, 10: 289-294.

Meshref, A.M. and Hassan, G.M. (2009): Bacteriological status of some soft cheeses sold in Beni-Suef City. Assiut Vet. Med. J., 55 (122): 112-123.
Mezyed, E.M.; Sharaf, E.M. and Abou El-Roos, N.A. (2008): Occurrence of some enteric pathogens in raw milk and some dairy products. Vet. Med. J. Giza, 51 (1): 29-36.

Moawad, A.A.; Galal, E.A.; Abd El-Hady, H.M. and Dardir, H.A. (2002): Role of dairy plant in improving some aspects of Kareish cheese. J. Egypt. Vet. Med. Assoc., 66 (2): 157-165.

Mossel, D.A. (1982): Microbiology of Foods. $3^{\text {rd }}$ Ed., The Univ. Utrecht, The Netherlands ISBN.

Omar, H.A. (2006): Bacteriological quality of some dairy products (Kareish cheese and ice cream) with special reference to salmonella in Alexandria. M.V.Sc. Thesis, Fac. Vet. Med., Alexandria Univ., Egypt.

Ray, B. (1996): Fundamental Food Microbiology. CRC press. Inc. Tokyo, New York.

Rippon, J.W. (1982): Medical Mycology. The Pathogenic fungi and pathogenic actinomycetes. W.B. Saunders Co., Philadelphia.

Robinson, R.K. (1990): Dairy Microbiology $2^{\text {nd }}$ Ed., Chapman and Hall, London, New York.

Sabioni, J.G.; Hirooka, E.Y. and Souza, M.De. (1988): Food poisoning from minas type cheese contaminated with Staphylococcus aureus. De saude Publica, 22: 428-446. (Dairy Sci. Abst., 51, 474).

Sayed, M. and Abdel-Haleem, Amal, A. (2005): Microbiological evaluation of some ready-toeat egg based desserts sold in Assiut City. Assiut Vet. Med. J., 51 (107): 113-125.

Sheliah, M.A.; Morgan, S.D. and Hafez, R.S. (1987): Indicators organisms in Egyptian cheese. Alex. J. Vet. Sci., 3 (2): 55-62.

Terplan, G.; Schoen, R. and Springmeyer, W. (1986): Occurrence, behavior and significance of Listeria in milk and dairy products. Arch. für Lebensmittelhyg., 37: 131-137.

Terplan, G.; Steinmeyer, S.; Becker, H. and Friedrich, K. (1990): Nachweis Van Listeria in Milch und Milch produkten. Arch. für Lebensmittelhyg, 41: 102-106.

Wahba, Nahed, M. (2002): Studies on Listeria species in milk and some milk products in Assiut Governorate. Ph.D. Thesis, Fac. Vet. Med., Assiut Univ., Egypt. 


\title{
المقارنة بين الجودة الميكروبيولوجية للجبن القريش المصنع من اللبن الخام والجبن القريش المصنع من اللبن المبستر المباعا في أسواق مدينة أسيوط من المين الخئ
}

\author{
محمود فرغلي حسين ، منال محمد أمين ، أنسي أديب صادق
}

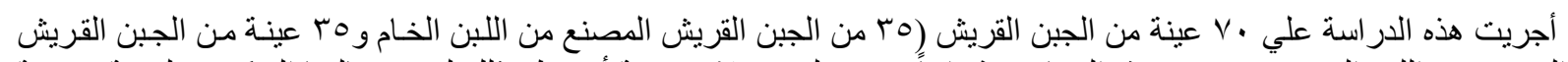

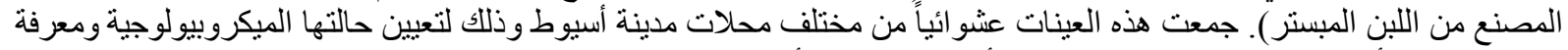

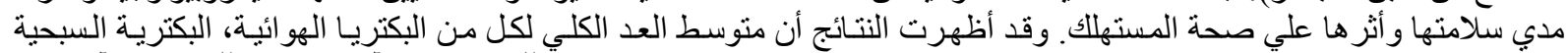

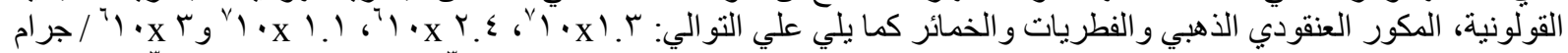

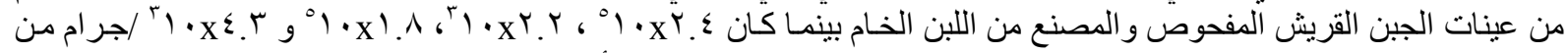

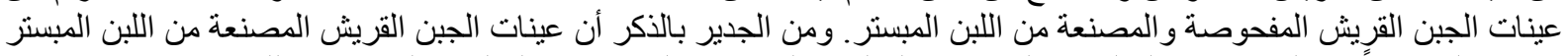

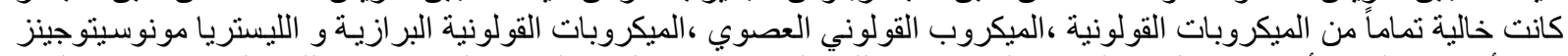

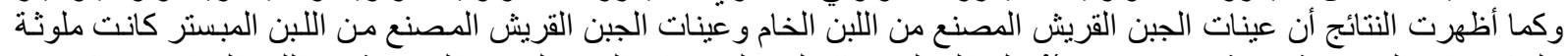

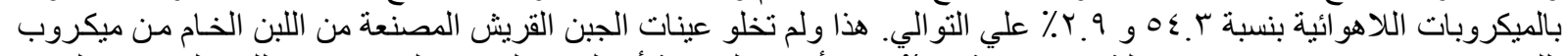

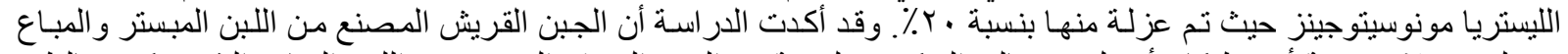

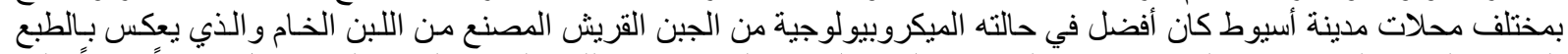

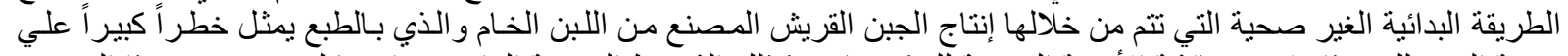

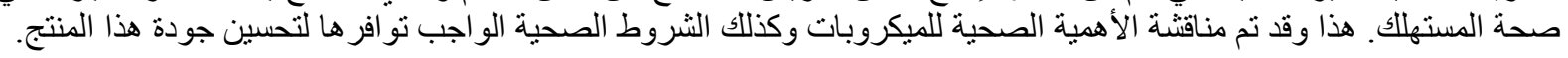

